\title{
An Investigation of Psychological Contract in Undergraduate Students
}

\author{
$\operatorname{Li~Li}^{1} \&$ Jingya Zhang ${ }^{2}$ \\ ${ }^{1}$ Guangdong University of Foreign Studies, China \\ ${ }^{2}$ The University of Melbourne, Australia \\ Correspondence: Li Li, School of English for International Business, Guangdong University of Foreign Studies, \\ Guangzhou, China. E-mail: 199110404@oamail.gdufs.edu.cn
}

Received: July 2, 2021

doi:10.5539/ijbm.v16n9p98
Accepted: August 3, 2021

Online Published: August 9, 2021

URL: https://doi.org/10.5539/ijbm.v16n9p98

\begin{abstract}
This study explores Chinese university students' perception of psychological contract. Using questionnaires and a quantitative approach, the study indicates that money issues, rewarding work, delegation of authority and flexible working hours are of utmost importance to these students. The study participants will start their working lives in one or two years. Knowledge of their perceived psychological contract has implications for human resource management hoping to improve the relationship between employer and new hires.
\end{abstract}

Keywords: psychological contract, Generation Y, employer and employee obligations

\section{Introduction}

Since 2012, more and more Generation Y has entered the labor market in China. Generation Y, or, millennial, refers to people who are born between 1980 and 1990s. In China, they are known as the post-80s and post-90s generations. They bring with them unique characteristics to the workplace. Most of them are well educated, confident and independent ( $\mathrm{Li} \&$ Hou, 2012). They strive for success (Tian, et al., 2015). They are highly decisive because they think they know what works best for them (Wu, 2007). Some Generation Yers do not like to conform to authority and are not afraid to challenge top management (Tian, et al., 2015). Compared with employees of older generations, Gen $\mathrm{Y}$ has a higher rate of turnover and a lower rate of organizational commitment (Xu \& Wang, 2015; Li, 2020; Tao \& Feng, 2020). Linkedin conducted a survey among its 150,000 users in China about their attitudes towards their first job after graduation. Data shows that post-95s generations experience job-hopping more frequently compared with employees of older generations. On average, they stay for only seven months with an employer and then withdraw from the company (China Daily, August 29, 2018, http://www.china.org.cn/china/2018-08/29/content_60844702.htm). How to retain and manage Generation Y employees? Currently, this issue challenges human resource management (Wu, 2007; Tian, et al., 2012; Hu \&Wang, 2020; Li, 2020; Tao \& Feng, 2020).

One of the suggested answers to the question is to seek more understanding of the psychological contract of Generation Y (Tian et al., 2012; Hu \&Wang, 2020; Li, 2020; Tao \& Feng, 2020). By knowing what they value most in the workplace, human resource management can formulate a series of policies and mechanism to motivate, develop, and retain them, and to create a win-win situation between the organization and employees.

Psychological contract refers to mutual expectations between employers and employees: what employers expect from employees and vice versa (Robbins \& Judge, 2017). For instance, employers are expected to provide higher salary, good working environment, and certain delegation of authority to employees. Employees are expected to generate high productivity, engage in organizational citizenship behavior, and project friendly demeanor in the workplace. Psychological contract is an unwritten contract. The interpretation of such contract is largely influenced by individual perception. One party's interpretation of the contract may not be consistent with that of another party (Parks \& Schmedemann, 1994). Specifically, this research will focus on employees' perspective and explore their views of employer and employee obligations (Rousseau, 1989). To be specific, the third and fourth year university students will participate in the study. The decision to choose them is based on the following two reasons. First, in one or two years' time, most of them will graduate and start their working lives in the organization. Second, even if they are currently university students, a mental framework of the psychological contract has already formed considering their part-time work experience and the access to the social media report of the work and employer-employee relationship. Understanding these millennials' perceived 
psychological contract will inform human resource managers of how to better design the recruitment and selection tool before millennials are employed and how to motivate and manage them after they are employed.

\section{Literature Review}

Research on psychological contract is multi-faceted. Some research (Wang et al., 2021; Kultalahti \&Viitala, 2015 ) focused on the identification of the factors that impact employees' psychological contract. One research (Wang et al., 2021) explores the psychological contract of 423 nursing assistants employed in 4 provincial tertiary A hospitals in Shanxi, China. Multivariate linear regression analysis showed that per capita monthly income of the family, compliance with training needs, years of employment, labor contract and social insurance were influencing factors of psychological contract perceived by nursing assistants. Kultalahti \&Viitala (2015) state working millennials in western countries consider workplace learning and development, challenging work, social relations and leader behavior, and time-related factors to be important elements of their psychological contract.

Other researchers (Kotter, 1973; Herriot et al., 1997; Turnley \& Feldman, 1999; Tian et al., 2015; Tao \& Feng, 2020; Chen, 2021) explore the impact of demographic characteristics on employees' psychological contract. Herriot et al. (1997) suggest that demographic factors such as age, gender and educational background have an impact on individuals' psychological contract. However, other researchers (Koc et al., 2013; Datla \& Dutta, 2016) hold different viewpoints. Based on the study involving 309 participants in Turkey, Koc et al. (2013) declare there is no significant gender difference in their perception of psychological contract.

In addition, the relationship between psychological contract and work-related issues have been explored. Chen (2021) conducts a research among 368 technicians in an IT company. It is noted that employees' psychological contract has a positive impact on their job involvement. If employees' psychological contract is breached, the level of employees' job involvement will decrease accordingly. Tian et al.(2015) investigate the relationship between psychological contract fulfillment (PCF) and relevant work behavior among 90 post-90s generation employees who have worked for one year in the organization. Result indicates that PCF has a positive effect on organization commitment and work acceptance, negative effects on turnover intentions, and insignificant effect on job performance. In a study of 232 medical staff in a hospital in China, $\mathrm{Li} \& \mathrm{Li}$ (2016) note that psychological contract breach is negatively related to employees' organizational commitment. Research also identified the relationship between psychological contract breach and turnover intention. Turnley \& Feldman (1999) point out that psychological contract violation will result in four potential employee responses: decreased loyalty and increased exit, voice and neglect. Similarly, Li \& Guo (2020) note the relationship of new hires' perceived psychological contract and their intention to resign.

Previous study on psychological contract has also been explored from the perspectives of participants with different educational level: MBA students (Rousseau, 1990), future employees just before graduation from the university (Michael, 2001), and final year university students (Markovic \& Stoilkovska, 2015). This study attempts to extend the topic by exploring the perceptions of the third and fourth year university students. Knowing millennial's perceptions of their own and their future employer's obligations can provide some insight into the way human resource management effectively recruit, select and manage these future employees.

Guided by the contributions of previous studies on psychological contract, this study aims to address the following questions:

1. What elements of employer and employee obligations are valued by university students?

2. Does demographic characteristic influence perception of psychological contract?

3. What elements of employee obligations would be affected if there were perceived under-fulfillment of employer obligations?

\section{Methods}

\subsection{Participants}

Participants in the research were third or final year students at a university located in the southern part of China. Questionnaire was conducted among 280 students, of which 265 completed and returned the questionnaire. The response rate was $95 \%$. 239 students' filled-in questionnaire were valid and showed $90 \%$ valid response rate.

\subsection{Questionnaire}

The questionnaire consists of two parts. The first part seeks demographic information concerning participants. The second part was questionnaire adapted from Rousseau (1990) and Michael (2001), and slightly modified. The analysis method of this study also replicated their research. Questions mainly include employer inducement 
(employer obligations to employee) and employee contributions (employee obligations to employer). Participants were asked to indicate the degree to which they agree or disagree with the statements concerning the reciprocal obligations. Five-point Likert scale is used, with 1 for "strongly disagree" and 5 for "strongly agree". Question such as "a job which you can make decisions by yourself" is in the category of employer inducement and question "work extra hours to get your job done" concerns the employee contribution.

\section{Results}

In total, 239 students participated in the research. 125 were female (52\%) and the majority of participants were English or business majors. 93\% of the participants had part-time work experience ranging from one to more than two years. Work experience is important because it plays a key role in participants' psychological contract formation. The profiles of the participants were depicted in Table 1.

Table 1. Profile of participants

\begin{tabular}{lll}
\hline & Number & Percentage of Total \\
\hline Grade in university & & \\
Third year student & 56 & 24 \\
Final year student & 183 & 76 \\
Gender & & \\
Male & 114 & 48 \\
Female & 125 & 52 \\
Major & & \\
English & 95 & 40 \\
Management & 78 & 33 \\
Economics & 31 & 12 \\
Arts & 35 & 15 \\
$\quad$ Part-time work experience & & \\
$>2$ years & 187 & 78 \\
1 - 2 years & 36 & 15 \\
$\quad<1$ year & 16 & 7 \\
\hline
\end{tabular}

An independent sample t-test was run to test whether there is gender difference in students' perception of employer inducement to the employees. Table 2 presents the mean, standard deviations and p-values of the scores. A slight and significant gender difference exists in the majority of the items $(\mathrm{p}<.05)$ regarding employer obligations, except for the item "performance-based pay". The mean score for male participants were higher than that of females on most of the items except for "long-term job security" and "sufficient power and responsibility", two items highly rated by female students.

Table 2. Gender difference in perceptions of employer inducement.

\begin{tabular}{|c|c|c|c|c|c|}
\hline & & & & & \\
\hline & Gender & Number & Mean & SD & Sig. \\
\hline \multirow{2}{*}{ Performance-based Pay } & $\mathrm{M}$ & 114 & 4.78 & 0.416 & 0.931 \\
\hline & $\mathrm{F}$ & 125 & 4.78 & 0.419 & \\
\hline \multirow{2}{*}{ Long-term job security } & M & 114 & 3.61 & 0.805 & $0.036 * *$ \\
\hline & $\mathrm{F}$ & 125 & 3.82 & 0.794 & \\
\hline \multirow{2}{*}{ Job in which you can make decisions by yourself } & M & 114 & 4.07 & 0.773 & $0.007 * *$ \\
\hline & $\mathrm{F}$ & 125 & 4.33 & 0.681 & \\
\hline \multirow{2}{*}{ Flexible working hours depending on personal need } & M & 114 & 4.53 & 0.552 & $0.017 * *$ \\
\hline & $\mathrm{F}$ & 125 & 4.34 & 0.659 & \\
\hline \multirow{2}{*}{ Training } & M & 114 & 4.37 & 0.732 & $0.000 * *$ \\
\hline & $\mathrm{F}$ & 125 & 3.89 & 0.961 & \\
\hline \multirow{2}{*}{ Attractive pay and benefits package } & M & 114 & 4.01 & 0.71 & $0.006 * *$ \\
\hline & $\mathrm{F}$ & 125 & 3.71 & 0.905 & \\
\hline \multirow{2}{*}{ Sufficient power and responsibility } & M & 114 & 3.74 & 0.81 & $0.004 * *$ \\
\hline & $\mathrm{F}$ & 125 & 4.02 & 0.672 & \\
\hline \multirow{2}{*}{ Promotion } & M & 114 & 4.2 & 0.766 & $0.000 * *$ \\
\hline & $\mathrm{F}$ & 125 & 3.77 & 1.017 & \\
\hline \multirow{2}{*}{ Opportunities to grow } & M & 114 & 4.6 & 0.51 & $0.001 * *$ \\
\hline & $\mathrm{F}$ & 125 & 4.31 & 0.734 & \\
\hline \multirow{2}{*}{ Rewarding work } & M & 114 & 3.7 & 1.013 & $0.000 * *$ \\
\hline & $\mathrm{F}$ & 125 & 2.87 & 0.992 & \\
\hline
\end{tabular}


Table 3 displays the result of the independent sample t-test run to see whether there is gender difference in employee obligations perceived by participants. The mean, standard deviations and p-values of the scores were presented in the table. Data shows that male and female university students hold similar views of many elements of employees' obligations to the organization. However, there are marked gender differences in items "refusing to support employers' competitors", "being loyal to employer", and "being an active team player". The mean score for the male participants were slightly higher than that of female students on these three items.

Table 3. Gender difference in students' perceptions of employee obligation

\begin{tabular}{llllll}
\hline & Gender & Number & Mean & S.D & P. \\
\hline Working extra hours & $\mathrm{M}$ & 114 & 3.02 & 1.072 & 0.590 \\
& $\mathrm{~F}$ & 125 & 3.10 & 1.167 & \\
Refusing to support employers' competitors & $\mathrm{M}$ & 114 & 3.54 & 0.988 & $0.000^{* *}$ \\
& $\mathrm{~F}$ & 125 & 2.98 & 1.15 & \\
Volunteering to do non-required task on the job & $\mathrm{M}$ & 114 & 2.96 & 0.935 & 0.408 \\
& $\mathrm{~F}$ & 125 & 2.84 & 1.201 & \\
Protecting confidential information about the company & $\mathrm{M}$ & 114 & 3.28 & 0.897 & 0.134 \\
& $\mathrm{~F}$ & 125 & 3.48 & 1.126 & \\
Loyal to employer & $\mathrm{M}$ & 114 & 3.22 & 1.119 & $0.025^{* *}$ \\
& $\mathrm{~F}$ & 125 & 2.86 & 1.297 & \\
Remaining with the company for at least 3 years & $\mathrm{M}$ & 114 & 2.80 & 1.09 & 0.621 \\
Abiding by organizational policies and norms & $\mathrm{F}$ & 125 & 2.72 & 1.33 & \multirow{2}{*}{0.833} \\
Being an active team player & $\mathrm{M}$ & 114 & 3.63 & 0.79 & \\
& $\mathrm{~F}$ & 125 & 3.66 & 0.976 & \multirow{2}{*}{$0.009^{* *}$} \\
Attending additional training courses & $\mathrm{M}$ & 114 & 3.69 & 0.766 & 0.854 \\
Willingness to accept a transfer & $\mathrm{F}$ & 125 & 3.42 & 0.854 & 0.087
\end{tabular}

Note. $* * \mathrm{P}<.05$

In order to identify what variables are necessary to understand association between the two sets of reciprocal obligations between employer and employee, a canonical correlation analysis method is used (Rousseau, 1990; Michael, 2001). Canonical correlation analysis is a multivariate method exploring the complex relationship in two sets of variables. It is frequently used in educational, psychological and business research. This study replicated the way Rousseau (1990) and Michael (2001) analyzed the data because it aims to identify the pattern of relation between the reciprocal obligations (Rousseau, 1990; Michael, 2001). Table 4 presents the association between reciprocal obligations perceived by male participants. The canonical dimension is statistically significant at .05 level. Canonical weight over 0.3 is significant. For the employer obligation variables, the canonical dimension is strongly influenced by "rewarding work", "jobs in which you can make decision by yourself", and "long-term job security". In return, participants will be "loyal to employers" and "willing to accept a transfer". The perceived employer violation of psychological contract will lead to a lack of employee obligations for "protecting confidential information about the company", "attending additional training courses" or "remaining with the company for at least 3 years".

Table 4. Males' perceptions of reciprocal obligations: canonical analysis

\begin{tabular}{|c|c|c|c|}
\hline Function & Canonical correlation & Wilk's Lambda & $p$ \\
\hline \multirow[t]{2}{*}{1} & .793 & .065 & .000 \\
\hline & & Canonical function weights & Canonical cross loadings \\
\hline \multicolumn{4}{|l|}{ Employer Inducement } \\
\hline Performance-based Pay & & .060 & .078 \\
\hline Long-term job security & & .375 & .032 \\
\hline Job in which you can make decisions by yourself & & -.501 & -.275 \\
\hline Flexible working hours depending on personal need & & .176 & .196 \\
\hline Training & & -.025 & .443 \\
\hline Attractive pay and benefits package & & .218 & .362 \\
\hline Sufficient power and responsibility & & -.066 & -.200 \\
\hline Promotion & & .005 & .327 \\
\hline Opportunities to grow & & -.137 & -.048 \\
\hline Rewarding work & & .735 & .701 \\
\hline
\end{tabular}




\begin{tabular}{lll}
\hline Employee Obligations & & -.333 \\
Working extra hours & .173 & -.116 \\
Refusing to support employers' competitors & .055 & -.320 \\
Volunteering to do non-required task on the job & -.078 & -.362 \\
Protecting confidential information about the company & -.777 & .124 \\
Loyal to employer & .779 & -.230 \\
Remaining with the company for at least 3 years & -.418 & -.091 \\
Abiding by organizational policies and norms & -.026 & -.035 \\
Being an active team player & .111 & -.477 \\
Attending additional training courses & -.569 & .256 \\
Willingness to accept a transfer & .343 & \\
\hline
\end{tabular}

Canonical correlation analysis was then conducted to understand female participants' perception of the association between the two sets of reciprocal obligations between employer and employee. Table 5 presents the result of the analysis. The canonical dimension is statistically significant at .05 level. Canonical weight over 0.3 is significant. For the employer obligation variables, the canonical dimension is strongly influenced by "flexible working hours depending on personal need", "jobs in which you can make decision by yourself", and "training". In return, female participants will be "volunteering to do non-required task on the job" "abiding by organizational policies and norms", "remaining with the company for at least 3 years" and "attending additional training courses". The perceived employer violation of psychological contract will lead to a lack of employee obligations for "working extra hours", and "refusing to support employers' competitors".

Table 5. Females' perceptions of reciprocal obligations: canonical analysis

\begin{tabular}{|c|c|c|c|}
\hline Function & Canonical correlation & Wilk's Lambda & $p$ \\
\hline \multirow{2}{*}{1} & .719 & .064 & .000 \\
\hline & & Canonical function weights & Canonical cross loadings \\
\hline \multicolumn{4}{|l|}{ Employer Inducement } \\
\hline Performance-based Pay & & -.233 & -.333 \\
\hline Long-term job security & & -.192 & .010 \\
\hline Job in which you can make decisions by yourself & & .353 & .201 \\
\hline Flexible working hours depending on personal need & & .619 & .520 \\
\hline Training & & .315 & .188 \\
\hline Attractive pay and benefits package & & -.177 & .120 \\
\hline Sufficient power and responsibility & & .100 & .346 \\
\hline Promotion & & .253 & .263 \\
\hline Opportunities to grow & & .256 & .379 \\
\hline Rewarding work & & .115 & .130 \\
\hline \multicolumn{4}{|l|}{ Employee Obligations } \\
\hline Working extra hours & & -.505 & -.121 \\
\hline Refusing to support employers' competitors & & -.450 & -.086 \\
\hline Volunteering to do non-required task on the job & & .687 & .191 \\
\hline Protecting confidential information about the company & & -.088 & .454 \\
\hline Loyal to employer & & -.133 & .255 \\
\hline Remaining with the company for at least 3 years & & .407 & .399 \\
\hline Abiding by organizational policies and norms & & .491 & .460 \\
\hline Being an active team player & & -.231 & .213 \\
\hline Attending additional training courses & & .176 & .372 \\
\hline Willingness to accept a transfer & & .319 & .491 \\
\hline
\end{tabular}

Table 6 presents the result of the canonical correlation analysis of both male and female participants' perception of the association between two sets of reciprocal obligations between employer and employee. The canonical dimension is statistically significant at .05 level. Canonical weight over 0.3 is significant. For the employer obligation variables, the canonical dimension is strongly influenced by "rewarding work", "jobs in which decision-making by oneself", "sufficient power and responsibility", and "attractive pay and benefits package". For the employee obligation variables, the canonical dimension is comprised of "loyal to employer", "attending additional training courses", "volunteering to do non-required task on the job", "remaining with the company for at least 3 years", and "refusing to support employer's competitors". Statistical analysis showed that, if participants believe their employer could provide rewarding work and attractive pay and benefits, they will show their loyalty to their employer and refuse to support company's competitors. Meanwhile, if participants perceive there is restricted decision-making power in the job they do, they are likely to respond by not engaging in organizational citizenship behavior, reduced work effort, and workplace withdrawal.

Table 6. Canonical correlations analysis between employer and employee variables: perceptions of male and 
female participants

\begin{tabular}{|c|c|c|c|}
\hline Function & Canonical correlation & Wilk's Lambda & $p$ \\
\hline \multirow[t]{2}{*}{1} & .674 & .165 & .000 \\
\hline & & Canonical function weights & Canonical cross loadings \\
\hline \multicolumn{4}{|l|}{ Employer Inducement } \\
\hline Performance-based Pay & & 0.085 & 0.063 \\
\hline Long-term job security & & 0.217 & -0.095 \\
\hline Job in which you can make decisions by yourself & & -0.422 & 0.378 \\
\hline Flexible working hours depending on personal need & & 0.023 & -0.038 \\
\hline Training & & -0.042 & 0.278 \\
\hline Attractive pay and benefits package & & 0.366 & 0.233 \\
\hline Sufficient power and responsibility & & -0.372 & -0.335 \\
\hline Promotion & & -0.132 & 0.095 \\
\hline Opportunities to grow & & -0.275 & -0.126 \\
\hline Rewarding work & & 0.614 & 0.505 \\
\hline \multicolumn{4}{|l|}{ Employee Obligations } \\
\hline Working extra hours & & -0.169 & -0.232 \\
\hline Refusing to support employers' competitors & & 0.352 & 0.032 \\
\hline Volunteering to do non-required task on the job & & -0.488 & -0.268 \\
\hline Protecting confidential information about the company & & -0.265 & -0.204 \\
\hline Loyal to employer & & 0.564 & 0.112 \\
\hline Remaining with the company for at least 3 years & & -0.432 & -0.171 \\
\hline Abiding by organizational policies and norms & & 0.041 & 0.008 \\
\hline Being an active team player & & 0.156 & 0.001 \\
\hline Attending additional training courses & & -0.565 & -0.503 \\
\hline Willingness to accept a transfer & & 0.246 & 0.069 \\
\hline
\end{tabular}

\section{Discussion}

Results show male and female participants differ in their perception of employer inducement. This contradicts previous study (Datla \& Dutta, 2016) stating there was no such difference in employees' perception of employer obligation. We suggest two reasons why this might be. First, individual's psychological contract is affected by a society's standard (Rousseau \& Schalk, 2000) and national culture (Thomas, et al., 2003). People from different societies and cultures develop different interpretations of the nature of psychological contract. Second, it is due to the different experience of the participants in the research. Participants in this study were university students who had part-time work experience whereas full-time employees from IT industry were recruited in other scholars' research (Datla \& Dutta, 2016). Difference in work experience will influence the way people perceive the employment relationship. Considering participants' perception of employee contribution, results indicate male and female participants hold similar views on many aspects. However, males ranked slightly higher than females in items such as "being loyal to employer", "refusing to support employer's competitors" and "being a good team player". The former two items relate to employee's organizational commitment. The finding is in line with some of the previous research (Aydin et al., 2011) about gender and organizational commitment: men tend to have stronger feeling of organizational commitment than women. The suggested explanation for the difference is that men have better salaries and organizational positions (Aydin et al., 2011) or that men are more likely to have commitment-enhancing jobs (Marsden et al., 1993). For another difference concerning "being an active team player", it also was consistent with other research (Cullinan, 2018) which shows that male and females have different perspectives on this issue.

Canonical correlation analysis of male's perceived reciprocal obligations indicates male participants value employer's obligation for rewarding work and delegation of authority while the analysis of female's perceived reciprocal obligations indicates they attach importance to employer's obligations for flexible working hours, delegation and training. Both male and female hold similar ideas about employee obligations. Correlation analysis of both male and female's perceived reciprocal obligations indicates research participants attach importance to both extrinsic and intrinsic factors in the workplace. They prefer highly-paid jobs. In addition, they also prefer taking challenging jobs. This is consistent with previous research (Kultalahti \& Viitala, 2015; Li, 2020) about new hires and their expectation of the organization. Kultalahti \& Viitala (2015) note that working millennials in the western countries prefers fair and competitive pay, flexible benefits, challenging work, and learning and development in the work. Meanwhile, correlation analysis of both male and female's perceived reciprocal obligations shows if participants perceive that relational psychological contract is under-fulfilled (e.g. restricted decision-making power in the job they do), they are likely to respond with less organizational 
citizenship behavior, reduced work effort, and withdrawal from the organization. This echoes a number of past research findings (Vantilborgh, et al., 2014; Xu \& Wang, 2015; Li, 2020; Tao \& Feng, 2020).

\section{Conclusion}

This study explores university students' perception of psychological contract. Results indicate that money issues, rewarding work, delegation of authority and flexible working hours are of utmost importance to both male and female students. In addition, their different ideas of psychological obligations have been presented. In particular, "rewarding work" tops the list in males' perception of employer obligations and "flexible working hours depending on personal needs" ranks first in females' perception of employer obligations. It is therefore suggested that human resource management should pay attention to the unique characteristics of psychological contract of Generation $\mathrm{Y}$ when formulating strategies regarding the management of these future employees.

Participants in this study are undergraduate students. In terms of their age, they are categorized as Generation Y. Their perception of the psychological contract is different from that of the employees of different generation group. As such, the generalizability of the research is limited. However, the result of this research can present human resource managers a picture about the millennials before they enter the workplace and some insight into the way human resource managers manage them after they are employed. For future research, semi-structured interview can be conducted to develop more understanding of university students' perception of the reciprocal relationship between employer and employee in the workplace.

\section{Implication for Practice}

Based on the above discussion, certain implications for human resource management practices are summarized as follows.

First, Generation Y has their unique psychological contract. Therefore, it is necessary to understand the elements that are critical and important to the psychological contract of this cohort. Results of this study show that money issues, rewarding work, delegation of authority and flexible working hours are of utmost importance to them. Thus, it is suggested that human resource management should take these factors into account when it comes to job design, compensation and benefits, and employee relation management.

Secondly, male and female participants hold different ideas about the importance of certain elements of reciprocal obligations. In particular, "rewarding work" tops the list in males' perception of employer obligations and "flexible working hours depending on personal needs" ranks first in females' perception of employer obligations. Being aware of these perceptual differences will assist human resource management in playing a good role, especially, in doing diversity management.

Thirdly, participants' perception of employer inducement fulfillment exerts impact on their organizational commitment (hereafter, OC). OC is positively related to productivity, job satisfaction, and organizational citizenship behavior (Tett \& Meyer, 1993; Wang, 2013). Thus it is suggested managers conduct employee survey on a frequent basis to seek understanding of employees' perceived psychological contract and take appropriate measures to enhance employees' OC.

Fourthly, delegation of authority is another issue of concern to these prospective employees. This is understandable. For most Generation Yers, they are the only child in their family. Compared with employees in other generation category, Generation Yers enjoy much more freedom in many aspects of their life. They are more likely to expect their voices to be heard either in personal life or organizational life. They are highly decisive because they think they know what works best for them (Wu, 2007). They do not like to conform to authority. Some Generation Yers are not afraid to challenge top management (Tian, et al., 2015). On this note, it will be reasonable to assume that delegation of authority matters to them. Jokisaari \& Vuori (2018) state that delegation has a positive relationship with new employees' work adjustment and job satisfaction. Job satisfaction, in turn, is negatively related to employees' turnover (Fasbender et al., 2019). Thus, delegation of authority to working millennials should be considered by human resource managers.

\section{References}


Aydin, A., Sarier, Y., \& Uysal, S. (2011). The Effect of Gender on Organizational Commitment of Teachers: A Meta Analytic Analysis. Educational Sciences: Theory and Practice, 11(2), 628-632.

Chen, M. J. (2021). Study on the relationship between psychological contract breach and job involvement of knowledge employees: The mediating role of job satisfaction. China Circulation Economy, 94-96. https://doi.org/10.16834/j.cnki.issn1009-5292.2021.07.030.

Cullinan, R. (2018). In collaborative work cultures, women carry more of the weight. The Harvard Business Review, 7 .

Datla, S., \& Dutta, T. (2016). Study of gender differences in perceived employer's obligations, it's fulfillment and relationship with job satisfaction. Indian Journal of Health \& Wellbeing, 7(6), 571-578.

Fasbender. U.. Van der Heiiden. B. I.. \& Grimshaw. S. (2019). Job satisfaction. iob stress and nurses' turnover intentions: The moderating roles of on-the-job and off-the-job embeddedness. Journal of advanced nursing, 75(2), 327-337. https://doi.org/10.1111/jan.13842

Herriot, P., Manning, W. E. G., \& Kidd, J. M. (1997). The content of the psychological contract. British Journal of management, 8(2), 151-162. https://doi.org/10.1111/1467-8551.0047

Hu, L.L., \& Wang, G. (2020). Research on incentive strategy of new generation employees from the perspective of psychological contract. Management and Administration, 9, 90-95. https://doi.org/10.16517/j.cnki.cn12-1034/f.2020.09.021

Jokisaari, M., \& Vuori, J. (2018). Leaders' resources and newcomer socialization: the importance of delegation. Journal of Managerial Psychology. https://doi.org/10.1108/JMP-09-2016-0274

Koc, H., Koc, B., \& Avci, C. (2013). The relationship between psychological contracts and organizational justice: A case study in accommodation establishments. American International Journal of Contemporary Research, $3(8), 51-58$.

Kotter, J. P. (1973). The psychological contract: Managing the joining-up process. California Management Review, 15(3), 91-99. https://doi.org/10.2307/41164442

Kultalahti, S., \& Viitala, R. (2015). Generation Y-challenging clients for HRM? Journal of Managerial Psychology, 30(1), 101-114. https://doi.org/10.1108/JMP-08-2014-0230

Li, H. J., \& Guo, Y. Z. (2020). An Empirical study on the impact of psychological contract on retention intention of Generation Y hotel employees - the moderating role of affective commitment. Productivity Research, 7 , 117-121. https://doi.org/10.19374/j.cnki.14-1145/f.2020.07.027

$\mathrm{Li}, \mathrm{N}$. (2020). Research on the incentive strategies for the new generation of "post-95" employees in small and medium-sized enterprises - based on psychological contract theory. Modern Business Trade Industry, 32, 66-68. https://doi.org/10.19311/j.cnki.1672-3198.2020.32.028

Li, S. R., \& Li, Y. F. (2016). Analysis of Effect of Engaging System Medical Staff Psychological Contract Breach on the Organizational Commitment in the Public Hospital. China Health Industry, 172-174. https://doi.org/10.16659/j.cnki.1672-5654.2016.30.172

Li, Y. P., \& Hou, X. F. (2012). The structure of new generation employees' work values and its influence on work behavior. Economic management, 5(5), 77. https://doi.org/10.19616/j.cnki.bmj.2012.05.009

Marković, Z., \& Stoilkovska, B. B. (2015). Final year university students' beliefs about future employment $\begin{array}{lllll}\text { relationships. Procedia-Social and Behavioral } & \text { Sciences, 171, }\end{array}$ https://doi.org/10.1016/j.sbspro.2015.01.091

Marsden, P. V., Kalleberg, A. L., \& Cook, C. R. (1993). Gender differences in organizational commitment: Influences of work positions and family roles. Work and Occupations, 20(3), 368-390. https://doi.org/10.1177/0730888493020003005

Michael, J. H. (2001). Perceived obligations of future forest industry employees: A psychological contracts perspective. Forest Products journal, 51(10), 39-46.

Parks, J. M., \& Schmedemann, D. A. (1994). When promises become contracts: Implied contracts and handbook provisions on job security. Human Resource Management, 33(3), 403-423. https://doi.org/10.1002/hrm.3930330309

Robbins, S. P., \& Judge, T. A. (2017). Organizational behavior. Pearson Education Asia Ltd. 
Rousseau, D. M. (1989). Psychological and implied contracts in organizations. Employee Responsibilities and Rights Journal, 2(2), 121-139.

Rousseau, D. M. (1990). New hire perceptions of their own and their employer's obligations: A study of psychological contracts. Journal of Organizational Behavior, 11(5), 389-400.

Rousseau, D. M., \& Schalk, R. (2000). Psychological Contracts in Employment: Cross-national Perspectives. Thousand Oaks, CA: Sage.

Tao, J. H., \& Feng, Y. (2020). Influence of organizational political climate on turnover intention of new generation employees and its governance path. Accounting Monthly, 3, 136-139. https://doi.org/10.19641/j.cnki.42-1290/f.2020.03.021

Tett, R. P.. \& Mever. J. P. (1993). Job satisfaction. organizational commitment. turnover intention, and turnover: path analyses based on meta-analytic findings. Personnel psychology, 46(2), 259-293.

Thomas, D. C., Au, K., \& Ravlin, E. C. (2003). Cultural variation and the psychological contract. Journal of Organizational Behavior: The International Journal of Industrial, Occupational and Organizational Psychology and Behavior, 24(5), 451-471. https://doi.org/10.1002/job.209

Tian, H. F., Liu, Z. Z., \& Wang, H. J. (2015). On the Influence of New Breed Employees' Psychological Contract on the Organizational Behavior__An Empirical Research Based on the Samples of Post -90 Generation Employees from Xi'an. Journal of Xihua University (Philosophy \& Social Sciences), 34(2), 85-90. https://doi.org/10.19642/j.issn.1672-8505.2015.02.015

Turnley, W. H., \& Feldman, D. C. (1999). A discrepancy model of psychological contract violations. Human resource management review, 9(3), 367-386. https://doi.org/10.1016/S1053-4822(99)00025-X

Vantilborgh, T., Bidee, J., Pepermans, R., Willems, J., Huybrechts, G., \& Jegers, M. (2014). Effects of ideological and relational psychological contract breach and fulfilment on volunteers' work effort. European Journal of Work and Organizational Psychology, 23(2), 217-230. https://doi.org/10.1080/1359432X.2012.740170

Wang, J., Xue, P., Guo, J. L., Hou, R., \& Xue, L. (2021). Study on status quo of psychological contract of nursing assistants and its influencing factors. Chinese Nursing Research, 35(6), 969-975. https://doi.org/10.12102/j.issn.1009-6493.2021.06.005

Wang, Y. S. (2013). Psychological contract, organizational commitment and job satisfaction among knowledge employees. China Journal of Health Psychology, 21(8), 1217-1219. https://doi.org/10.13342/j.cnki.cjhp.2013.08.012

Wu, X. Y. (2007). The characteristics and Management Countermeasures of new generation employees. Human Resource Management Development, 2(4), 44-46. https://doi.org/10.16471/j.cnki.11-2822/c.2007.02.015

Xu, Z. Q., \& Wang, L. Q. (2015). Research on the New Generation Employees Changing Jobs Frequently Based on the Psychological Contract Theory. Journal of North China Electric Power University (Social Sciences), 2, 87-90. https://doi.org/10.14092/j.cnki.cn11-3956/c.2015.02.017

\section{Copyrights}

Copyright for this article is retained by the author(s), with first publication rights granted to the journal.

This is an open-access article distributed under the terms and conditions of the Creative Commons Attribution license (http://creativecommons.org/licenses/by/4.0/). 